\title{
CERCETĂRI ARHEOLOGICE ÎN VATRA ORAŞULUI DE FLOCI (PIUA PETRI), COMUNA GIURGENI, JUDEȚUL IALOMIT,A.
}

\author{
Anca Păunescu, Dana Mihai, Silviu Oța, Gheorghe Matei.
}

\section{RECHERCHES ARCHÉOLOGIQUES DANS LA ZONE DE LA VILLE DE FLOCI (PIUA PETRII), COMMUNE GIURGENI, DÉPARTEMENT DE LA IALOMIȚA}

\section{Résumé}

Pour diverses raisons, les résultats des dernières recherches archéologiques effectuées sur ce site ont été présentés partiellement. Pendent les années 1998-1999, les recherches ont été poursuivies sur les Grinds no 2, 3 et no 6 - ouest. Sur le Grind no 2, nous avons terminé la recherche de la nécropole no 5, qui sera publiée séparément. Sur le Grind no 6, à l'ouest du fragment de mur de l'église no 1, nous avons fait des investigations sur une zone d'habitations et d'ateliers artisanaux. Nous avons constaté que le plancher de certaines d'entre elles avait été refait 2 ou 3 fois. L'atelier a été détruit par un incendie.

Comme suite des modifications dans la composition de l'équipe de recherches, à partir de l'année 2000, les recherches se sont focalisées sur les Grinds no 1 et 3 dans le but de découvrir la disposition des habitations et le système de lotissement des grandes surfaces. Sur le Grind no 1, deux habitations ont été découvertes, composées chacune de deux chambres de superficies inégales. La distance entre ces deux habitations était de 6 mètres. L'habitation no 1 découverte dans la Section I B/2003 constitue une découverte exceptionnelle. A l'extérieur de celle-ci, adossée au mur sud-ouest, une plate-forme de pierre était disposée sur une couche de terre glaise. Cette habitation date du milieu du XVII-ème siècle. Suite à son abandon, deux fours ont été construits sur cette plate-forme, entraînant sa destruction partielle. Pour le moment, nous ne sommes pas fixés sur l'objet d'utilisation de cette plate-forme.

En octobre 2003, nous avons été sponsorisés pour réaliser des investigations archéogéophysiques effectuées par le personnel du Laboratoire Mobile de Prospection Archéogéophysique de BCUM - Alba Iulia. L'objectif principal était d'obtenir des informations relatives à l'habitation avec une éventuelle précision des objectifs d'intérêt archéologique sur le Grind no 9 situé dans la partie ouest de la ville. En 2004 et 2005, nous avons effectué deux sections de sondages pour vérifier les dates fournies par l'interprétation de cette investigation. Pour le moment, nous pouvons signaler l'éventuelle existence d'une nécropole.

Les recherches sur le Grind no 3 ont mis en évidence trois niveaux d'habitations datés entre la deuxième moitié du XV-ème siècle et le début du XVIII-ème siècle.

Mots cléf: habitations des $\mathrm{XVI}^{\mathrm{e}}-\mathrm{XVII}{ }^{\mathrm{e}}$ siècles

Cuvinte cheie: locuințe, secolele XVI-XVII

Din motive obiective rezultatele ultimelor campanii de cercetări arheologice efectuate în vatra fostului oraş medieval au fost prezentate parțial. (Păunescu 1998-2000, Coman, Rența, Matei, Oța 2003).

În cursul campaniei din anul 1998 s-a încheiat cercetarea Necropolei nr. 5 (sector Grind $n r .2$ ), pe care urmează să o publicăm separat. În limita vestică a acestei mari necropole au fost descoperite resturile unui atelier de olărie şi două cuptoare de ars ceramica, care au funcționat în a doua jumătate a secolului XVII (Păunescu 1998-2000).

Tot în campania din anul 1998 s-au continuat cercetările şi în sectorul Grind $n r .6$ vest Mănăstirea. Obiectivul nostru a fost acela de a investiga densitatea şi dispunerea locuințelor în raport cu Biserica nr. 1. În acestă zonă a fost surprinsă stratigrafic o suprafață foarte întinsă de pământ galben lutos, steril din 
punct de vedere arheologic, în care erau numeroase gropi pentru depunerea rezidurilor menajere. Presupunem că într-o primă fază a aşezării, de aici s-a extras lutul necesar pentru construirea locuințelor şi a confecționării cărămizilor din chirpic. În prima jumătate a secolulu XVII, această suprafață a fost nivelată cu un strat de pământ cu aspect granulos, de culoare cenuşiu-brun, inegal ca grosime. Peste această nivelare s-a extins un cartier de locuințe şi ateliere, încadrat cronologic între a doua jumătate a secolului al XVII-lea şi prima jumătate a secolului XVIII, după cum atestă analiza inventarului arheologic descoperit. În campaniile de cercetări arheologice din anii 1998 şi 1999 au fost identificate şi cercetate parțial 12 locuințe de suprafaţă, cu plan dreptunghiular, ridicate din chirpic pe o structură din bârne de lemn. La unele locuințe au putut fi observate 2-3 faze de refacere a podelei din lut. Pe suprafața acestor podele s-au descoperit resturi de vetre, fie ale unor sobe cu cahle, fie ale unor cuptoare.

Cercetarea locuinței-atelier pentru prelucrarea bronzului, interceptată în campania din 1998, la o distanță de circa 30 m spre sud-vest de locuințele mai sus menţionate, s-a continuat şi în anul 1999. Acest atelier $(7,70 \mathrm{~m} \mathrm{x} 9 \mathrm{~m})$ a fost amenajat peste stratul de nivelare, mai sus aminti. Locuința a fost distrusă de incendiu. De pe suprafaţa podelei au fost recuperate monede, turte de bronz, deşeuri de tablă de bronz. (Oța, Pârvan 2003) În apropierea acestui atelier s-au descoperit urmele parțial a altor trei locuințe, cu faze de refacere în urma incendiilor care le-au distrus.

\section{Sector Grind nr.1}

Datorită unor schimbări intervenite în componența colectivului, începând din vara anului 2000, ne-am propus concentrarea cercetărilor pe Grindul $n r$. 1, unde în cursul campaniilor anterioare fuseseră descoperite şi cercetate atât biserica nr. 2 cât şi 15 locuinţe de suprafață, precum şi o locuință cu pivniță în care s-au găsit resturile unei sobe cu cahle smălțuite, decorate cu imaginea Sfântului Gheorghe, ateliere meşteşugăreşti, vetre în aer liber, gropi menajere. (Chițescu et alii, 1981). Pe baza materialului arheologic descoperit şi a analogiilor cu privire tipologia acestuia s-a stabilit că locuința cu pivniță a fost ridicată în primul sfert al secolului XVII.
Prin cartarea acestor descoperiri, pe planul general al sitului, intenționăm să obținem informații asupra sistemului de lotizare în funcție de amplasarea bisericii nr. 2 într-un sector al vetrei oraşului.

Pornind din limita sudică a Grindului $n r$. 1, acolo unde în anii 1994-1997 au fost descoperite locuințe de suprafață şi locuința cu pivniță şi gârlici, mai sus amintită, a fost trasată o secțiune mediană pe suprafața grindului, orientată N.-S. şi casete necesare pentru dezvelirea complexelor. A fost surprinsă în continuare existența celor două nivele de locuire, datate din a doua jumătate a secolului XV şi în secolele XVI-XVII, ambele distruse în urma unor puternice incendii. Între locuințe au fost descoperite numeroase gropi pentru depozitarea rezidurilor menajere, ce au străpuns aceste nivele de locuire şi care, pe baza analizei inventarului arheologic, aparțin nivelului ultim de locuire din cursul secolelor XVII-XVIII, distrus de lucrările agricole ulterioare abandonnării vetrei oraşului.

S-a constatat că după după incendierea oraşului din anul 1470, locuitorii au curățat terenul, depozitând resturile de chirpic ars şi cenuşa în gropi mari, alveolate, rezultate în urme scoaterii lutului folosit la construcția locuințelor. După aceea au nivelat terenul cu pământ adus sau cu o peliculă de lut purtat, aproximativ peste urma locuințelor incendiate. Orăşenii şi-au ridicat noile case, folosind aceiaşi tehnică de construcție, dar uneori cu planurile uşor modificate. Între locuințele noi au fost descoperite resturile a două cuptoare, vetre în aer liber şi ateliere rudimentare de prelucrare a fierului în vederea obținerea unor obiecte de uz: lame de cuțit, cuie sau balamale pentru lucrările de tâmplărie. Deocamdată s-a observat în partea de nord a Grindului nr.1 că limita amplasării locuințelor mai timpurii din primul nivel este mai restrânsă fața de cea a nivelului II, ce aparține secolelor XVI-XVII. Până în prezent nu deținem nici un indiciu care să sugereze că această zonă a aşezării a fost locuită anterior primei jumătăti a secolului XV.

În anul 2002 traseul secțiunii mediane a intersectat aria cimitirului şi zidurile fundaţiei din zona absidei bisericii nr. 2, cercetată în anii 1977-1979. (Chițescu et alii 1979). După înlăturarea stratului de humus vegetal, în suprafața 
secțiunii au apărut zone de arsură, amestecate cu fragmente mărunte de cărămidă, fragmente ceramice (în special de la oale cahlă), oase sparte şi rare spărturi de piatră provenite probabil de la demantelarea bisericii nr. 2 , precum şi câțiva bolovani de râu. Între acestea se desena, în suprafața secțiunii, conturul unor gropi târzii pentru depunerea rezidurilor menajere şi resturile unor vetre de cuptoare, distruse de lucrările agricole. Încă odată s-a verificat observația că aici înhumările s-au continuat în cimitirul din jurul bisericii chiar şi după distrugerea edificiului şi abandonarea de către locuitori a vetrei oraşului, aşa cum indică monedele otomane (Mahmud I, 1730-1745), descoperite în inventarul mormintelor săpate în nivelul de dărâmătură. Această limită a cimitirului, aflată la distanța de $14 \mathrm{~m}$ față de zidul absidei de nord a bisericii, a apărut marcată în teren printr-un şanț lat de 3,70 m şi adânc de $1,80 \mathrm{~m}$ faţă de nivelul actual de călcare, cu pereții săpați vertical şi fundul aproape plat. Umplutura acestui şanț s-a făcut lent, cu reziduri menajere şi nu este relevantă din punct de vedere al inventarului arheologic. De asemenea s-a mai constatat că locuințele ce aparțineau nivelul II au fost ridicate în imediata vecinătate a acestui şanț din limita nordică a cimitirului

În timpul campaniei de cercetări arheologice din anul 2003 secțiunea mediană a fost prelungită în continuare cu încă $40 \mathrm{~m}$ spre limita de nord a grindului şi au fost dezvelite integral două locuințe de suprafață ale căror resturi erau mai bine păstrate pentru reconstituirea planului lor (Chițescu et alii 1979)

Aproximativ în mijlocul secțiunii I. din anul 2003, la adâncimea de $-0,50 \mathrm{~m}$ față de nivelul actual de călcare, a apărut o masă compactă de chirpic ars care acoperea urmele unei locuințe cu două încăperi, ridicată pe tălpi din bârne cu pereții din chirpic (Loc. 1/S.I B), asemănătoare prin modul de construcție cu locuințele de suprafață din lemn şi chirpic descoperite în campaniile anterioare (fig. 1).

Latura sud-vestică a locuinței era mărginită de un pavaj realizat din bolovani de râu, de mărimi diferite, cu lăţimea de $1,30 \mathrm{~m}$ aşezați pe un strat de lut curat, cu grosimea de circa $0,15 \mathrm{~m}$. Ulterior, acest pavaj a fost spart în limita exterioară de groapa unui cuptor rotund $(1,10 \times 1,25 \mathrm{~m})$, distrus din vechime. Conturul cuptorului cu urma vetrei şi dimensiunile sale se aseamănă cu cuptoarele de ars ceramica din a doua jumătate a secolului XVII, descoperite pe Grindul 2, în limita unui vast cimitir- necropola nr. 5 (Păunescu 1998-2000).

Pentru cercetarea completă a acestei locuințe au fost trasate şi două casete, paralele cu laturile secțiunii, păstrându-se între ele un martor de $0,50 \mathrm{~m}$. Locuința dezvelită integral avea un plan dreptunghiular $(8 \times 4,75 \mathrm{~m}) \mathrm{cu}$ laturile lungi, marcate de bârnele-talpă, orientate nord est. Interiorul era compartimentat în două incăperi cu dimensiuni inegale $(5,75$ x $4,50 \mathrm{~m} ; 1,50 \times 4,50 \mathrm{~m}$ ) printr-un perete ce a fost ridicat de asemenea pe o bârnă-talpă, paralelă cu latura orientată sud-est. Aproximativ în centrul camerei mari au fost descoperite două gropi de pari, cu distanța de $1 \mathrm{~m}$ între ele, care susțineau probabil căpriorii acoperişului, iar aproape de colțul nordic al aceleiaşi încăperi s-au găsit resturile de lut ars la roşu, compact, acoperite de o peliculă de cenuşe pietrificată, care proveneau de la vatra unei sobe. Semnalăm că în masa de chirpic ars, prăbuşită pe podeaua locuinței, în zona acestei vetre s-au găsit şi o mulțime de fragmente mărunte de oale-cahlă (fig. 2).

S-a constatat că platforma din bolovani de râu se continua numai pe lungimea laturii camerei mari, orientată sud vest, prezentând o lățime maximă de $3,50 \mathrm{~m}$. Limita vestică a pavajului este foarte bine precizată prin dispunerea bolovanilor pe platforma de lut. În limita pavajului din caseta paralelă cu peretele vestic al secțiunii a fost amenajat ulterior al doilea cuptor rotund. În profilul secțiunii se observă că podeaua locuinței şi pavajul de pietre erau aşezate pe un strat gros de lut, care suprapunea un strat de pământ de umplutură, de nivelare, adus şi depus direct peste stratul de lut nisipos, steril din punct de vedere arheologic. În acest pământ de umplutură s-au descoperit fragmente ceramice atipice dar şi câteva fragmente mărunte de ceramică orientală, foarte multe oase de animale, şi o lamă de cuțit. Prezența fragmentelor de ceramică orientală în acest strat ne-a determinat să presupunem că locuința cercetată ar aparține primei jumătăți a secolului XVII. Această încadrare cronologică a fost confirmată de descoperirea unei monede în masa de chirpic ce acoperea punctul de îmbinare 
a două bârne-talpă. Moneda este o imitație moldovenească, databilă între 1661-1668 (falsuri Dabija) după un şiling de Riga (1632-1654).

Dacă planul şi modul de construcție al locuinței este comun locuințelor din lemn şi chirpic descoperite în acest centru urban, platforma de bolovani de râu prezintă o excepție. Este dificil să apreciem rolul funcțional al acesteia. În primul rând prezența amenajărilor cu piatră este un lucru destul de rar în acest sit. Avem cercetate trei biserici cu temelie din piatră şi câteva locuințe sub a căror bârne talpă s-au găsit blocuri de piatră paralelipipedice. În general s-a presupus că piatra folosită de orăşeni a fost adusă din carierele de la Hârşova. În cazul pavajului prezentat mai sus s-au folosit bolovani de râu, de diferite mărimi, care nu prezintă nici o urma de prelucrare. Cei care au confecționat acest pavaj, adosat locuinței, au ținut seama că amenajarea se făcea pe un strat de umplutură, de nivelare, care ar fi cedat la greutatea masei de bolovani şi aşa cum am arătat mai sus, au construit mai întâi o platformă de lut, groasă, aliniată la nivelul podelei şi al bârnei talpă de la temelia casei, ca suport pentru ca pavajul să-şi mențină orizontalitatea, în ciuda greutății. $\mathrm{Ne}$ întrebăm în ce scop a fost realizat acest pavaj. S-ar putea să fi fost atelierul unui meşteşugar. In campaniile anterioare au fost descoperite câteva locuințe-atelier ale unor meşteri care prelucrau oasele de animale în vederea obținerii nasturilor din os, a plăselelor pentru cuțite sau a altor obiecte de uz. Podelele acestor ateliere erau şi ele amenajate din pietre de râu, dar de dimensiuni mult mai mici decât cele din pavajul amintit, bătute într-un strat foarte subțire de lut. În toate cazurile acestor ateliere pe podelele amenajate astfel a fost descoperită o mare cantitate de spărturi de oase, deşeuri, sau piese în diferite faze de prelucrare amestecate cu piese finite (Lungu 1981). În cazul pavajului de bolovani de râu nu avem nici un indiciu. Datorită faptului că locuința a fost părăsită în mod deliberat, şi pavajul a fost ulterior distrus prin amenajarea celor două cuptoare de ars ceramica, funcționalitatea acestei amenajări rămâne incertă.

Datorită inventarului foarte sărac recoltat de pe suprafața podelei din lut a locuinței (câteva fragmente de străchini sau farfurii smălțuite, un fragment de cahlă placă pe care se vede un fragment din corpul unui balaur din reprezentarea iconografică a Sfântului Gheorghe, călare, sub picioarele căruia se afla balaurul ucis), constatăm că acest complex a fost abandonat deliberat, înainte de distrugerea lui prin incendiu.

Ca o observație preliminară putem afirma că sub locuința mai sus descrisă, nivelul de locuire atribuit secolului XVI nu a mai fost surprins. Terenul prezintă o pantă lungă, uşor înclinată care poate în acea vreme se afla în zonă inundabilă, între meandrele brațului Ialomiței vechi care străbăteau oraşul. La începutul secolului al XVIIlea, s-ar putea ca datorită sporului demografic, să se extindă zona de ridicare a caselor. Aşa s-ar explica stratul gros de pământ de umplutură, aflat sub podeaua şi pavajul locuinței, depus direct pe lutul steril arheologic.

Tot în cusul acestei campanii s-a continuat şi cercetarea unei alte locuințe, (Loc.2-S. I. B-2003) interceptată parțial în secțiunea I. din anul 2002, la o distanță de $6 \mathrm{~m}$. spre sud de locuința mai sus descrisă. A fost descoperită o zonă de lut bine bătătorit, acoperită cu cenuşe şi bulgări de chirpic ars. După înlăturarea bulgărilor de chirpic, în lutul bătătorit s-au păstrat lăcaşurile cu resturile a două bârne-talpă, care se îmbinau în unghi drept. În anul 2003 s-a trasat o casetă paralelă cu peretele vestic al secțiunii, cu un martor de $0,50 \mathrm{~m}$ cu scopul de a dezveli integral acestă locuință. După îndepărtarea stratului de humus vegetal, a apărut o zonă de arsură în limita sudică a casetei, prinsă în peretele ei. Între bugării mari de chirpic, amestecați cu pământ negru, oase şi fragmente de ceramică orientală din care s-a întregit gâtul unei căni cu toartă, şi fragmente de farfurii smălțuite (fig. 3).

Planul locuinței cercetate este tot de formă dreptunghiulară, marcat prin traseul bârnelor-talpă, distruse parțial. Laturile lungi (cca. $8 \mathrm{~m}$ ) erau orientate nord-est. Locuința a fost compartimentată în două încăperi inegale ca dimensiuni $(6,75 \times 5,75 \mathrm{~m} ; 1,25 \times 6,75 \mathrm{~m})$, printr-un perete paralel cu laturile scurte, orientat sud vest-nord est. Podeaua locuinței, din lut bătut, a fost distrusă de gropi ulterioare. În colțul de nord est s-au găsit pe podeaua de lut resturile unei vetre de sobă amestecat cu fragmente ceramice ce proveneau de la oale- 
cahlă şi oale cu toartă dintre care s-au întregit 4 oale-cahle şi o ulcică (fig. 4/1).

Intre aceste două locuințe descrise, la adâncimea de $-0,50 \mathrm{~m}$ şi $-0,62 \mathrm{~m}$ s-au descoperit antrenate în strat, pe pământul galben, două monede: un dinar, 1520, emis de Ludovic al II-lea al Ungariei şi o monedă otomană, mangâr din vremea sultanului Selim I, 1514-1520.

În concluzie, s-a observat că cele două locuințe cercetate aveau aceiaşi orientare, care sugerează alinierea lor la o tramă stradală. Singura deosebire este modul de compartimentare, în sensul amplasării camerei de mai mici dimensiuni, spre nord sau spre sud. În ambele cazuri, urma vetrei sobei s-a găsit pe suprafața podelei în camera mare, principală, în apropierea colțului de nord est, cea ce ar sugera indirect poziția uşii, a fațadei casei față de artera de acces sau circulație.

Anca Păunescu, Irina Ene

\section{Sector Grind nr. 9.}

Aşa cum se constată atât pe teren cât şi din ridicarea topografică, pe suprafața vetrei acestui oraş abandonat se observă zone înalte-grinduri despărţite între ele de albia şi meandrele unui braț mai vechi a râului Ialomița. Se presupune că legătura între ele era asigurată de existența unor poduri sau punți. Cercetările arheologice întreprinse până în prezent pe grindurile $1,3,6$, arată că zonele înalte ale acestor grinduri au fost intens locuite. S-a constatat că după distrugerile prin incendiere ale locuinţelor din acest oraş, locuitorii păstrau lotizările existente şi-şi refăceau casele peste urmele celor vechi, în linii mari păstrându-se planul lor.

În luna octombrie $2003 \mathrm{am}$ beneficiat de o sponsorizare pentru realizarea unor prospectiuni arheogeofizice efectuate de către personalul Laboratorului Mobil de Prospecții Arheogeofizice al BCUM-Alba Iulia. Obiectivul principal a fost obținerea unor informații cu privire la caracterul locuirii, cu o eventuală precizare a obiectivelor de interes arheologic pe grindul nr. 9, aflat spre limita vestică a vetrei oraşului.

Cercetarea sistematică a grindului s-a făcut prin utilizarea a două metode de prospectare într-o manieră complementară: tomografia electrică a solului şi magnetometria. Paralel cu prospectarea arheogeofizică, s-a realizat şi ridicarea topografică de detaliu, cu scopul de a poziționa clar toate măsurătorile efectuate în teren. Metodologia prospecțiilor a fost prezentată în anul 2004, la sesiunea anuală de rapoarte arheologice, la Cluj.

Interpretarea datelor obținute de echipa Laboratorului Mobil de Prospecții Arheogeofizice a condus la formularea unei ipoteze asupra existenței pe acest grind a unei situații arheologice tipice unei aşezări de tip urban relativ dezvoltată, cu rețele stradale, clădiri din zid cu fundație de piatră şi un eventual zid de fortificare cu un presupus şanț cu apă, pe latura sudică.

Pornind de la aceste ipoteze foarte promițătoare, în campania de cercetări arheologice din anii 2004-2005 am întrerupt continuarea cercetării şi studierii dispunerii locuințelor de pe Grindul nr. 1 şi am trasat 2 secțiuni de sondaj pe Grindul nr. 9 pentru verificarea informațiilor furnizate de prospecțiunile arheogeofizice: rețele de drumuri, fundații din piatră, clădiri din cărămidă sau şanț cu apă.

În suprafața terenului, Grindul nr. 9 se prezintă ca o platformă mai înaltă, de formă aproximativ triunghiulară cu vârful orientat spre est şi baza spre vest (fig. 5).

La circa $50 \mathrm{~m}$ distanță spre Vest de acest vârf am trasat Secținea I/2004 de sondaj, (50 x $2 \mathrm{~m}$ ) orientată nord-sud, pentru a surprinde mai ales zona în care, conform interpretării compexului de anomalii prospectate, se contura ipoteza existenței unei construcții cu rol aparte. Secţiunea a fost trasată şi peste limita sudică a grindului, în valea care îl delimitează de Grindul nr. 8, în zona unde prospecțiunile amintite indicau existența unui zid de apărare, lung, continuu, care limita aproape toată latura sud-vestică a grindului. Dincolo de zid, se contura o incintă cu urmele unei clădiri în centru. Această construcție cu caracter aparte părea să fie incinta unui locaş de cult, a unei mănăstiri, mărginită pe latura opusă zidului de apărare de un şir de locuințe aliniate la o presupusă tramă stradală.

După observațiile noastre acumulate în cursul cercetărilor, existența construcției unui zid de piatră continuu era destul de improbabilă într-o zonă joasă, inundabilă. Mai mult, construcțiile de zid cu piatră sunt extrem de rare în vatra oraşului. Excepție fac fundațiile celor trei biserici descoperite şi construcția din piatră 
a fundației unei case, descoperită în primii ani ai cercetărilor arheologice (Chițescu et alii 1979) care presupunem că a făcut parte din construcția unei mori de apă, instalații existente în vatra oraşului şi menționate în documente.

Profilul secţiunii indică o stratigrafie oarecum asemănătoare celor de pe grindurile investigate arheologic în campaniile anterioare.

După îndepărtarea stratului de pământ vegetal cu o grosime medie de $0,30 \mathrm{~m}$, urmează un strat de pământ cenuşiu granulat amestecat cu fragmente ceramice mărunte, neîntregibile, provenite de la vase de uz nesmălțiite, o mare cantitate de oase de animale, fragmente de chirpic și de cărbuni. Spre centrul grindului, în mijlocul acestui strat s-a surprins o linie de arsură, pe alocuri întreruptă, care anunță un orizont de locuinte incendiate. Grosimea stratului de locuire variază între $0,40 \mathrm{~m}-0,60$ $\mathrm{m}$. Pe o porțiune de circa $7 \mathrm{~m}$, acest nivel de locuire este întrerupt de un strat de pământ cenuşiu afânat, la baza căruia au fost surprinse în profil gropile a trei morminte de copii (infans I-II), care se adâncesc până în stratul de lut steril. Posibil ca aceste morminte să anunțe existența unui cimitir şi a unei biserici mai spre centrul suprafeței grindului.

Profilul peretelui secțiunii spre panta sudică a grindului indică un strat gros de scurgere a materialui arheologic specific nivelului ultim de locuire şi nu s-a identificat nici o urmă de fundație a unui presupus zid de fortificare, iar şanțul cu apă este de fapt albiaprival al unui braț al Ialomiței vechi care străbătea vatra oraşului în vechime. Deocamdată nu putem formula vreo explicație pentru mica platformă din jumătăți de cărămidă care a apărut în profilul vestic al secțiunii, în zona pantei din capătul sudic al secțiunii. Asemenea mici platforme au mai apărut şi în cuprinsul secțiunilor din campaniilor anterioare, fără să fie în legătură cu un complex anume. Sub stratul de humus vegetal se afla o peliculă de chirpic ars, care provenea de la o locuință din lemn şi chirpic, distrusă de un incendiu. Aceasta a apărut la adâncimea de $-0,32 \mathrm{~m}$ sub nivelul actual de călcare şi are o lățime de $0,40 \mathrm{~m}$.

Stratul se lut steril arheologic apare la adâncimea de $-0,80 \mathrm{~m}$ dar sunt şi zone, mai ales spre centrul grindului, când acesta se ridică la cota de $-0,50 \mathrm{~m}$. față de nivelul actual de călcare.
Secțiunea I/2004 a mai fost prelungită în anul următor cu încă $10 \mathrm{~m}$ spre sud, peste şanțuirea din teren, unde măsurătorile arheofizice indicau existența acelui zid de apărare. S-a ajuns până la adâncimea de $-1,20$ m, într-un strat gros de pământ negru, granulos, lipsit de material arheologic.

Secțiunea II/2005 $(75 \times 1,5 \mathrm{~m})$ a fost trasată paralel cu S.I/2004, la o distanță de 46,5 $\mathrm{m}$ spre vest. Capătul nordic al secțiunii se afla în zona cea mai înaltă a grindului, iar capătul sudic tăia din nou valea în care era indicat de către prospecțiunile arheofizice acel zid de apărare. În lungul secțiunii, după îndepărtarea stratului de humus vegetal arat, se întinde un strat de cultură, deranjat de arătură, în care s-au găsit fragmente ceramice ce provin de la forme de vase nesmălțuite, pigment de cărbune, fragmente de chirpic ars, multe oase sparte, spărturi de piatră şi două monede (denar, Ferdinand I, Ungaria; para, Imperiul Otoman, Ahmed III, 1703-1730). Imediat sub stratul de humus vegetal, în ultimul carou din capătul nordic al secțiunii, s-a descoperit o mică porțiune de lut galben în care erau grupate spărturi de piatră, un fragment de cărămidă şi lângă ele jumătatea inferioară a unei ulcele. Presupunem că este vorba de o vatră care a funcționat scurt timp, deoarece lutul era foarte puțin înroşit din cauza arderii. Pe toată lungimea secțiunii, la adâncimea de $-0,50 \mathrm{~m} \mathrm{~s}$-a observat prezența unui strat de lut, gros de cca. 0,12 $0,15 \mathrm{~m}$ depus ca o nivelare. Aproape de capătul nordic al secțiunii, aproximativ în zona mai înaltă a grindului, la adâncimea de circa $-0,50 \mathrm{~m}$, s-au conturat gropile a trei morminte care săpate în stratul de nivelare. Subiectii înhumați, doi adulți şi un adolescent se aflau la adâncimea de $0,75 \mathrm{~m}$ fată de nivelul actual de călcare. Distanța între morminte era de $1,25 \mathrm{~m}$. La mică distanță de M.1, la adâncimea de $-0,90 \mathrm{~m}$, a fost descoperită a treia monedă din a doua jumătate a secolului XVI (fals după un denar Ungaria). Mormintele nu au putut fi cercetate din cauza timpului nefavorabil.

În concluzie, zidul presupus pe latura sudică a grindului nu există şi ar fi fost surprinzătoare existența lui într-un loc inundabil, cu atât mai mult cu cât în aria sitului, cu excepția fundațiilor deja amintite, nu au fost descoperite în stadiul actual al cercetării alte construcții din piatră. Trama stradală nu a fost 
surprinsă. Acest fapt pare destul de dificil de interpretat deoarece dărâmăturile rezultate în urma incendierilor au fost nivelate neregulat şi acoperite cu un strat subțire $(\mathrm{cca} .5-10 \mathrm{~cm})$ de lut nisipos.

S-ar putea presupune existența ruinelor unei biserici, atât prin faptul că în periegheză a fost observată o zona spre mijlocul suprafeței grindului, unde la suprafață era concentrată o cantitate apreciabilă de spărtură de piatră şi de cărămizi cu urme de mortar pe ele, cât şi prin prezența gropilor de morminte apărute în cele două secțiunii.

Materialul arheologic recoltat este foarte puțin relevant pentru estimarea datării urmelor de locuire. Fragmentele ceramice, neîntregibile, foarte mărunte, provin de la vase de uz nesmălțuite, specifice mai ales secolului XVII.

Desenul profilului secțiunii ne pune în fața unei realități care a fost surprinsă pe celelalte grinduri cercetate în campaniile anterioare. Şi anume, datorită lucrărilor agricole, ultimul nivel de locuire al oraşului a fost distrus. Existența lui a fost surprinsă numai în inventarul gropilor de depozitare a rezidurilor menajere. Şi aici pare să se repete prezența celor două nivele distruse prin incendiu şi datate în cursul secolelor XVI-XVII.

In acest stadiu, ipotezele formulate prin prospectarea combinată a celor două metode mai sus enunțate trebuie verificate şi în cursul campaniilor viitoare.

Anca Păunescu, Dana Mihai.

\section{Grindul nr. 3.Sector Avicola}

În anul 2004 cercetarea a continuat pe grindul nr.3-est, fiind deschise trei casete (C.13) şi în partea sa de est, la sud de săpătura efectuată în anul 2001 de către Emilia Corbu (Muzeul Județean Ialomița). Noile casete deschise au avut dimensiunile de $4 \times 4 \mathrm{~m}$ şi au fost orientate pe direcția nord-sud. Martorii dintre ele au avut lățimea de 0,5 m. Față de C.1, C.2 a fost trasată la sud de ea, $\operatorname{iar} C .3$ la vest de prima. Fiecare casetă a fost împărțită în patru carouri, fiecare cu dimensiunea de $2 \times 2 \mathrm{~m}$. Descrierea complexelor se va face de jos în sus.

\section{Locuința $n r .1$}

Suprapune o groapă menajeră $(G r$. 2/2004) în colțul de sud-est al C.2/2004 şi $G r$. 1/2004, în colțul de sud-vest al aceleiaşi casete. A fost identificată în C1./2004. Din întreaga locuință nu s-au mai găsit decât câteva resturi de podea incendiată suprapuse de chirpic ars şi o vatră adâncită, cu diametrul de $0,47 \mathrm{~m}$. Dimensiunile reale şi orientarea, datorate situației stratigrafice, nu se pot preciza $\mathrm{cu}$ exactitate.

Locuința este suprapusă de o depunere de pământ maro, cu grosimi variabile. Peste acest strat de pământ, a fost găsită o amenajare de lemn, incendiată. Aceasta suprapune $G r$. 2/2004 şi un colț al Loc. 1/2004. În partea de est a casetei $2 / 2004$, lemnul a fost aşezat direct pe nivelul de pământ steril. Rolul acestei amenajări, în acest stadiu al cercetării nu poate fi precizat. Peste ea este un alt strat de pământ maro, suprapus la rândul său de o amenajare similară, de lemn incendiat, cu grosimea de 2 $\mathrm{cm}$, observabilă pe profilele de nord şi de est ale C.2/2004 (fig. 6, 7).

\section{Locuința nr. 2}

A fost surprinsă în C.1/2004 şi în C.2/2004. Locuința, orientată NV-SE, cu dimensiunile de 4,75 x 4,20 m, constă într-o podea de lut (a fost observată cu unele întreruperi, şi avea o grosime de $0,04-0,08 \mathrm{~m}$ ) peste care au fost montate podele de lemn (grosimea lor este variabilă, între 0,02 - 0,04 m). Acestea din urmă au fost incendiate. Pereții locuinței erau construiți pe tălpi din lemn, din chirpic şi nuiele. Tălpile din lemn au fost fixate pe alocuri pe pietre. Elevația incendiată a fost găsită căzută peste podele. Peste locuință exista un strat de pământ maro cu fragmente de lemn carbonizat şi chirpic ars (fig. 6, 7).

\section{Locuința nr.3}

A fost identificată pe profilul nordic C.1/2004 şi pe cel estic al C.2/2004. A fost cercetată parțial şi a avut două faze de refacere. Constă în podele de lemn montate pe straturi de lut. La colțuri existau meloane de dimensiuni mijlocii pentru fixarea tălpilor locuinței. Orientarea era similară cu cea a locuinței precedente (fig. 6, 7).

\section{Locuința nr.4}

Orientată pe direcția NV-SE, a fost găsită peste stratul de pământ maro, depus peste 
complexele precedente şi este observabilă în C.1/2004 şi C.2/2004 (fig. 6, 7).

Între această locuință şi precedenta este un strat de pământ maro cu grosimi variabile, între $0,08-0,12 \mathrm{~m}$.

Locuința constă într-o podea subțire de lut $(0,02-0,08 \mathrm{~m})$; pe unele profile, peste lut, se observă un strat de pământ cenuşiu cu urme de chirpic şi lemn carbonizat. În partea de nordest a complexului a fost găsită o vatră în forma literei „C" $(0,44 \times 0,54 \mathrm{~m}$, la o adâncime de $0,47 \mathrm{~m})$, cu deschiderea spre sud-vest. Din elevație nu s-a mai păstrat nimic.

Din datele obținute în urma cercetării, pare a fi mai degrabă un complex cu o durată foarte scurtă de folosire. Dimensiunile sale aproximative sunt de 5,25 x 7,00 m.

\section{Locuința $n r .5$}

A fost orientată NV-SE şi este surprinsă în profilul nordic al C.1/2004 la adâncimea de $0,21 \mathrm{~m}$ până la $-0,42 \mathrm{~m}$, imediat sub pământul arabil. În profilul estic este o piatră, care a avut probabil rolul de a susține talpa. Podeaua constă într-un strat de lut (cu grosimi variabile de 0,03 $-0,13 \mathrm{~m}$ ), peste care au fost montate scânduri de lemn (grosimea lor a fost de 0,02-0,04 m). Aceasta a fost sesizată în zona metrului 3 (pe profilul nordic) şi se adânceşte în colțul casetei deoarece o parte a ei suprapunea Gr. 3/2004. Pe profilul estic este observabilă până la $1,74 \mathrm{~m}$, unde a fost tăiată de Gr.5/2004. Aceasta porneşte de sub pământul arabil, taie chirpicul din elevația locuinței şi podeaua acesteia. Pereții au fost construiți din chirpic şi stâlpi de lemn (unul, cu grosimea de $0,10 \mathrm{~m}$, a fost identificat la adâncimea de $0,23 \mathrm{~m}$, în afara podelei carbonizate). Grosimea stratului de chirpic este variabilă, o parte a sa fiind distrusă de lucrările agricole recente (mai bine păstrat este acolo unde a suprapus groapa menajeră). Complexul a fost incendiat, iar pereții erau căzuți peste podeaua de lemn (fig. 6).

\section{Locuința $n$ r.6}

Este observabilă la adâncimi variabile $(-0,26-0,36 \mathrm{~m})$ pe profilul de nord şi de vest al C.1/2004 şi în planul C.3/2004, imediat sub stratul de pământ arabil. Aceasta constă într-o amenajare de lut (cu grosimea de 0,02-0,08 m, întreruptă pe alocuri) peste care au fost montate scânduri de lemn, tălpi din lemn fixate pe pietre, o sobă de cahle, elevație din chirpic şi o amenajare de pietre şi cărămizi în colțul de sudvest. Locuința a fost distrusă prin incendiere.

Podeaua incendiată este sesizabilă la adâncimi variabile şi are o grosime de $2-5 \mathrm{~cm}$. Urme din ea au fost înregistrate şi în C.2/2004, pe profilul nordic (între $1,10 \mathrm{~m}$ şi $2,93 \mathrm{~m}$, de la vest la est) şi în plan (urme de cenuşe în C.1/2004 şi pământ ars şi cenuşe în C.2/2004).

Elevația este arsă şi căzută peste podea; a fost bulversată în mare parte în urma lucrărilor agricole.

Soba a fost amenajată pe un paviment de fragmente de cărămizi. Din zonă au fost recuperate fragmente de cahle diverse, dintre care unele decorate cu imaginea Sfântului Gheorghe, iar altele traforate. Ca amplasament, se găsea în camera cu podea de lemn.

Amenajarea cu lut, prin întindere, coroborată cu zona ocupată de podeaua de lemn, care o suprapunea doar parțial, demonstrează faptul că a fost o locuință cu două încăperi şi probabil un cerdac.

Dimensiunile complexului, orientat NVSE, au fost de 4,00 x 5,50-6,00 m (fig. 6, 7).

\section{Groapa $n r .1$}

Identificată în colțul de SV al C.2/2004 (fig. 7 - profilul sudic al cas. 2/2004). Cercetată parțial, a fost săpată în steril. Adâncimea era de $0,21 \mathrm{~m}$ de la nivelul de călcare medieval. Dimensiunile nu se pot încă preciza.

\section{Groapa $n r .2$}

În colțul de SE al C.2/2004 (fig. 7 profilul estic al cas. 2/2004). A fost cercetată parțial şi este săpată în steril. Adâncimea este de $0,60-0,64 \mathrm{~m}$ de la nivelul de călcare medieval. Dimensiunile nu se pot preciza.

\section{Groapa nr. 3}

În partea de NE a C.1/2004 (fig. 6 profilul nordic al cas. 1/2004). Cercetată parțial. A tăiat Loc.2 şi 3/2004.

\section{Groapa $\mathrm{nr} .4$}

Aflată în parte de Nord a C.1/2004 (fig. 6 - profilul nordic al cas. 1/2004). Cercetată parțial. A tăiat Loc. 2 şi 3/2004. 


\section{Groapa $n r .5$}

Aflată în partea de Est a C.1/2004, pornea imediat de sub stratul de pământ arabil a fost cercetată parțial.

\section{Groapa $n$ r. 6}

Aflată în partea de Sud-Vest a C.3/2004. Conținea o mare cantitate de ceramică.

Pentru a putea plasa în timp utilizarea acestor complexe, vom folosi cronologia relativă şi cea absolută. Cronologia relativă este oferită în special de fragmentele ceramice de import (de tip Miletus şi Iznik). Cea absolută este dată de o singură monedă emisă în anul 1586, la Riga, în timpul lui Ştefan Bathory ${ }^{1}$. Moneda, prin poziția sa stratigrafică, indică faptul că stratul de pământ maro care suprapune locuințele 1, 2 şi $3 / 2004$ se poate data la sfârşitul secolului XVI. Aceasta înseamnă că în porţiunea de est a Grindului nr. 3, în zona cercetată, locuințele care stratigrafic sunt deasupra acestor reziduri menajere, trebuie datate în secolul XVII.

Fragmentul ceramic de tip Miletus, a cărui producție a încetat în jur de 1470 (Coman, Rența, Matei, Oța 2003), poate data Loc.2/2004 probabil în ultimul sfert al secolului XV. Pe acelaşi Grind, în partea sa de Nord, a mai fost descoperit un fragment ceramic de acelaşi tip (Mihai 1997), care provenea dintr-un strat de pământ care a suprapus o locuință incendiată. De asemenea, Loc.1/2004, Gr.1 şi Loc.2/2004 sunt anterioare acestei date.

Loc. 3/2004, conform stratigrafiei, este posterioară Loc. 3/2004, deci poate aparține cel mai probabil primei jumătăţi a secolului XVI. Zona cu stratul de pământ cu reziduri menajere care le suprapune s-a format până la sfârşitul secolului XVI sau începutul veacului următor. Din aceeaşi vreme se poate data $G r$. 3/2004 şi Gr. 4/2004.

Ceramica de Iznik (fragmente), datorită faptului că a fost descoperită în diverse poziţii stratigrafice, aparține unor perioade diferite precum şi datorită faptului că aceasta este în cele mai multe situații amestecată, nu poate constitui un indiciu cronologic foarte exact. Ceea ce putem spune în acest stadiu, este că

\footnotetext{
1 Mulțumim pe această cale domnului Aurel Vâlcu pentru determinarea monedelor.
}

predomină ceramica decorată cu motive pictate cu albastru şi verde închis şi deschis. Smalţul este atât mat, cât şi lucios. Din punct de vedere al formelor, s-au descoperit boluri, căni şi un fragment de farfurie. Cronologic, această ceramică se poate data de la sfârşitul secolului al XV-lea, până la începutul secolului XVII.

Materialul ceramic recuperat este extrem de sărac şi provine în special din afara locuințelor. Aceasta constă în special din ceramică de uz comun (fragmente de ulcioare, căldare de lut, vase borcan), ceramică smălțuită (fragmente de boluri şi farfurii) şi cahle ornamentate (cu imaginea Sfântului Gheorghe, traforate, sau cu motive vegetale). Piesele mărunte sunt şi ele în număr mic şi constau din fragmente de cuțite, fusaiole din fragmente ceramice, verigi din fier, fragmente de recipiente de sticlă, un astragal ornamentat cu crestături, un fragment de pandantiv.

Silviu Oța,

Tot pe Grindul nr. 3 Avicola ${ }^{2}$, un alt sector se află la vest de zona necropolei nr. 3 , unde cercetările arheologice întreprinse din vara anului 2001 au avut un caracter de salvare (fig. $10)$.

În cursul anului 2004, cercetările arheologice s-au continuat pe Secțiunea 1/2003 şi caseta adiacentă trasată pe latura de nord a secțiunii, impuse de cota de adâncime $-0,60 \mathrm{~m}$ la care s-a ajuns în campania anterioară, când nu a fost finalizată cercetarea stratului de cultură identificat. Secțiunea 1/2003 avea o lungime de $40 \mathrm{~m}$ şi cu lățimea de $2,50 \mathrm{~m}$ iar caseta A trasată pe latura de nord în dreptul carourilor 10-16 avea dimensiunile de 14 x 6 m (Păunescu, Coman, Corbu, Costea 2003).

Lângă latura vestică a secțiunii $1 / 2003$, în carourile 1-9, la adâncimea de $-0,90-1,20 \mathrm{~m}$, s-au mai descoperit şi cercetat 14 morminte de inhumație, care aparțin necropolei nr. 3, cercetată în campanile anterioare, datată în secolele XVI-XVII. Orientarea mormintelor este est-vest, cu mici abateri şi acestea erau dispuse în şiruri paralele, pe direcția nord-sud. Majoritatea mormintelor aparțin unor adulți. Unele morminte (M. 76-78) au fost deranjtate de gropi de provizii sau suprapuse de locuințe

\footnotetext{
${ }^{2}$ Sectorul Muzeului Județean Ialomița-Slobozia.
} 
(L. 1/2003). Inventarul funerar descoperit este relative sărac şi se compune din 2 inele (M. 67, M. 74), o monedă otomană (M. 78) şi o cataramă (M. 70).

Inelele sunt lucrate dintr-o sârmă de argint torsionată cu o montura formată dintr-o pastilă aplatizată, de formă rombică, cu colțurile rotunjite, decorată prin incizie cu un motiv în formă de soare cu raze. Prin analogie aceaste piese pot fi datate la începutul secolului al XVI-lea (fig. 11/3).

\section{Locuintele.}

Locuința 1/2003 a fost identificată în campania precedentă, între carourile 6-9. Stratigrafic, s-au constatat trei nivele de refacere ale podelei. Cel mai vechi nivel al podelei locuinței s-a aflat la adâncimea de $-0,90$ $\mathrm{m}$, iar ultimul nivel de refacere s-a aflat la adâncimea de $-0,50 \mathrm{~m}$ față de nivelul actual de călcare. Locuința 1/2003 suprapune mormintele din zona estică a secțiunii $1 / 2003$. Aceasta a fost cercetată parțial.

Locuința 2/2003 era situată în partea de nord a secțiunii, între carourile 10 şi 14 şi în caseta A. S-a păstrat podeaua din lut, cu dimensiunile laturilor de 5,50 x $5,40 \mathrm{~m}$, delimitată de bârnele din lemn în care se fixau parii verticali care susțineau pereții. În colțul de NE s-au găsit două pietre folosite la fixarea bârnei-talpă. Tot în această zonă s-a păstrat, la nivelul podelei $(-0,75 \mathrm{~m})$ şi vatra instalației de încălzit şi prepararea hranei, amenajată pe un pat de pietre de râu. Pe latura sudică a vetrei se afla groapa de golire plină cu cenuşe şi spărturi de oase. Lângă vatră s-a găsit o oală -cahlă. Cercetările din anul 2005 efectuate în zona centrală a casetei au scos la iveală o bârnă talpă de la Locuința nr. 3/2004, orientată N-S, care indica existența a două camere despărțite printr-un perete interior. La est de bârna talpă a apărut vatra unei sobe $(0,40 \times 0,40 \mathrm{~m})$ aflată în camera dinspre vest a locuinței menționate. Continuarea cercetării a scos la iveală faptul ca sub Locuința 3/2004 se aflau resturile a altor două locuințe la adâncimi diferite

Locuința 3/2004, situată tot în caseta A, suprapune locuința $2 / 2003$, fiind departajată de aceasta printr-un strat de nivelare din lut galben cu grosimea de $0,30 \mathrm{~m}$. Podeaua locuinței a fost surprinsă la adâncimea de $-0,50 \mathrm{~m}$ față de nivelul actual de călcare. Orientarea laturilor
(7,50 x $4 \mathrm{~m})$ este EV-NS. Pentru consolidarea fundației s-au folosit pietre găsite în colțul de NV şi SE şi pe traseul bârnei talpă al laturii de NE. În unele zone s-au mai păstrat resturile unui pavaj din cărămizi. In cursul cercetărilor din anul $2005 \mathrm{~s}$-a putut complecta planul care arată că locuința era compartimentată în două încăperi, cu dimensiuni inegale, şi în fiecare cameră s-au descoperit resturi ale vetrelor.

Locuința 4/2004 se afla la nord de locuința 2/2003, la adâncimea de -1 m, delimitată parțial pe latura vestică prin bârne, iar spre est printr-un grupaj de bârne prăbuşite.

Tot în secțiunea $1 / 2003$, în caroul 20, la adâncimea de $-1,10 \mathrm{~m}$ a fost surprinsă bârna de la podeaua altei locuințe -Locuința 5/2004- ce urmează să fie cercetată în campaniile viitoare. Tot în această secțiune au fost descoperite şi cercetate două gropi pentru reziduri menajere, în carourile 6-7, suprapuse de locuința 1/2003. Inventarul arheologic al acestor gropi se compunea din fragmente ceramice, un vârf de săgeată, un cârlig pentru pescuit (fig. 11/1, 4).

În privința încadrării cronologice a acestor complexe, locuința $2 / 2003$ ar putea fi datată în prima jumătate a secolului XVI, cu ajutorul unei monede (ducat polonez, 1521, Sigismund, Lituania) descoperit pe podeaua ei. Aceasta este suprapusă de locuința $3 / 2004$, care poate fi datată în a doua jumătate a secolului XVI (fig. 12).

Remarcăm prezența în locuințele menționate a greutăților de pescuit, dintre care una are pe suprafața ei incizate semne „runice”, a fragmentelor de cahle decorate cu modele geometrice sau cu imaginea Sfântului Gheorghe, numeroase fragmente de ceramică nesmălțuită şi smălțuită.

În campania din anul 2005, paralel cu Secțiunea $1 / 2003$, în nord, s-a trasat o nouă secțiune, S. 3/2005 (18 x 3 m) care se opreşte în caseta $A$, adiacentă la S1/2003. Scopul trasării lui S. 3/2005 a fost interceptarea şi cercetarea necropolei nr. 3 şi continuarea dezvelirii locuinței L. 1/2003, delimitată între carourile 69. Aici au fost descoperite şi cercetate urmele a trei locuințe suprapuse, care sunt separate între ele prin lentile de pământ galben, folosit pentru nivelarea terenului.

Locuințele au fost notate astfel: L.1/a, L.1/b, L. 1/c. 
Locuința nr. 1 a/2005 are podeaua din lut situată la adâncimea de $-0,50 \mathrm{~m}$, având orientarea $\mathrm{E}-\mathrm{V}$ şi dimensiunile laturilor de $6 \times 4$ $\mathrm{m}$ Sub L.1, la adâncimea de $-0,58-0,60 \mathrm{~m}$, s-a cercetat Locuința. nr. 1 b/2005, cu podeaua acoperită cu bârne de lemn cu diametrul de 0,30 m. Pe podeaua acestei locuinte s-a descoperit un ulcior întreg (fig. 13/2), o greutate de pescuit din piatră. Tot în locuință a fost cercetată şi vatra de formă ovală a unei sobe, situată în NNE., cu dimensiunile de 1,07 x 0,82 m, construită din cărămizi aşezate ca un postament, între ele găsindu-se şi $o$ cărămidă dreptunghiulară $\mathrm{cu}$ una din laturile mici terminată în forma de triunghi. Tot lângă această vatră s-au găsit materiale ceramice, din care remarcăm un sfeşnic (întregit) decorat cu smalț verde (fig. 13/1) şi un castron decorat cu smalț galben, un fragment de cahlă pe care este reliefată o cruce şi o figură umană.

Locuința nr. 1 c/2005, situată pe acelaşi amplasament se află situată la adâncimea de $0,80 \mathrm{~m}$., acoperită de un strat de chirpic ars, care păstrează aceleaşi dimensiuni şi orientare.

Podelele locuințelor descrise mai sus, ne permit să concluzionăm ca locuințele aveau aceiaşi orientare, $\mathrm{V}-\mathrm{E}$, şi aceleaşi dimensiuni de $6 \times 4 \mathrm{~m}$, iar fiecare refacere era însoțită obligatoriu de o nivelare a zonei, efectuată cu pământ galben compactat, pentru a mări rezistența solului, în vederea ridicării construcției şi chiar pentru a proteja pereții din chirpic ai locuinței de umiditate.

Pe S.3/2005, paralelă cu latura de nord a secțiunii I/2003, între carourile 1-6, s-a ajuns la adâncimea de $-1 \mathrm{~m}$, unde au apărut morminte ce aparțin necropolei nr. 3, dar datorită timpului nefavorabil şi expirării timpului de cercetare ele au fost conservate pe loc.

Locuința 6 din S. 1/2003 şi caseta A, situată în zona vestică, situată la adâncimea de $0,60 \mathrm{~m} \mathrm{cu}$ orientarea laturii lungi $\mathrm{N}-\mathrm{S}$, era construită din chirpic. Dimensiunile ei erau de 6 m x $4 \mathrm{~m}$. Pe suprafața podelei s-au găsit greutăți de lut pentru plasa de pescuit şifragmente de ceramică nesmălțuită şi smălțuită, provenite de la ulcioare, farfurii decorate.

Locuința nr. 7 din S. 1./2003 şi caseta A, era situată sub L.6, la adâncimea de $-0,80 \mathrm{~m}$, orientată E-V, va fi cercetată în campaniile din anul viitor.

Pe baza datărilor făcute în campania din 2004, nivelul I de locuire (L.1/c, L.4, L.7, L.5) se datează în a doua jumătate a secolului $\mathrm{XV}$, nivelul II (L.1/b, L.2, 6) se datează la începutul secolului XVI (datat şi cu moneda emisă în anul 1521, descoperită în L.2 /2003), iar nivelul III (L.1/a, L.3) se datează la sfârşitul secolului XVI şi începutul secolului XVII.

Rezultatele cercetărilor din anul 2005, corelate cu cele din anii 2003-2004, desfăşurate pe suprafață mare, au scos la iveală existența în zona vestică de pe Grindul nr. 3 Avicola a unei intense locuiri, cu trei nivele de locuințe, unde au fost cercetate 9 locuințe din paiantă, unele ridicate pe bârnă - talpă din lemn. Aici s-au stabilit 4 grupări de locuințe cu distanțe mici între ele, 2-3 m, şi se poate observa o aliniere a lor cu orientarea V-E şi precum şi existența unei "ulițe" în zona de sud a locuințelor cercetate. Cercetările care se vor efectua în anii următori spre est, pe axul V-E, vor aprofunda situația surprinsă în acest perimetru.

Gheorghe Matei

\section{BIBLIOGRAFIE}

Păunescu, Oța, Matei 2004 - Anca Păunescu, Siviu Oța, Gheorghe Matei, Cronica Cercetărilor Arheologice din România. Campania 2004, Mangalia, 2005, p. 161-164

Coman, Rența, Matei, Oța 2003 - Radu Coman, Elena Rența, Gheorghe Matei, Siviu Oța, Raport de cercetare arheologică pe anii 2001-2003 la Oraşul de Floci (Comuna Giurgeni, Jud. Ialomița), Cercetări Arheologice XII, Bucureşti, 2003, pp. 45-56.

Păunescu, Coman, Corbu, Costea 2003 - Anca Păunescu, Radu Coman, Emilia Corbu, Irina Costea, Cronica Cercetărilor Arheologice din România. Campania 2003, Cluj-Napoca, 2004, p. 129.

Păunescu, Ene 2003 - Anca Păunescu, Irina Ene, Cronica Cercetărilor Arheologice din România. Campania 2003, p. 129. 
Oța, Pârvan 2003 - Silviu Oța, Katia Pârvan, Monede medievale descoperite la Oraşul de Floci (Piua Petri), jud. Ialomița, în campanile arheologice din anii 1996, 1998-1999, Cercetări Arheologice XII, Bucureşti, p.241-247.

Păunescu, Coman, Corbu, Costea 2001, Anca Păunescu, Radu Coman, Emilia Corbu, Irina Costea, Cronica Cercetărilor Arheologice din România. Campania 2001, Buziaş, 2002, p. 144-145.

Păunescu, Mihai, Oța, Costea 2000 - Anca Păunescu, Dana Mihai, Silviu Oța, Irina Costea, Cronica Cercetărilor Arheologice din România. Campania 2000, Suceava, 2001, p. 91-92.

Păunescu 1998-2000, Anca Păunescu, Cuptoare medievale descoperite la Oraşul de Floci, județul Ialomița, Cercetări Arheologice XI, partea I-a, Bucureşti, 1988-2000, p. 175-185.

Mihai 1997, Dana Mihai, Ceramica de Iznic descoperită la Oraşul de Floci, județul Ialomița (I), Cercetări Arheologice X, Bucureşti, 1997, p. 277-290.

Chițescu, Păunescu, Mihai, Teodor, Oța 1996 - Lucian Chițescu, Anca Păunescu, Dana Mihai, Silviu Teodor, Silviu Oța, Cronica Cercetărilor Arheologice. Campania 1996, Bucureşti, 1997, p.44-45.

Chițescu et alii 1981 - Lucian Chițescu, Radu Lungu, Teodor Papasima, Petre Vlădilă, Venera Rădulescu, Anca Păunescu, Cercetări arheologice în anul 1979 la Piua Petri (Oraşul de Floci), comuna Giurgeni, jud. Ialomița, Cercetări Arheologice IV, 1981, p. 126-132.

Lungu 1981 - Radu Lungu, Contribuții la istoria meşteşugurilor medievale în Țara Românească, Revista de Istorie, 1981, tom 34, nr. 3, p. 513-519.

Chițescu et alii 1979 - Lucian Chițescu, Nicolae Conovici, Radu Lungu, Anca Păunescu şi Venera Rădulescu, Cercetări arheologice la Piua Petri(Oraşul de Floci), jud. Ialomița, Cercetări Arheologice III, 1979, Bucureşti, p. 224-228.

\section{LÉGENDES DES FIGURES}

Fig. 1. L'habitation no. 1.

Fig. 2. Plan de l'habitation no $1-\mathrm{S}$. I B/2003.

Fig. 3. Plan de l'habitation no $2-\mathrm{S}$ I B/2003.

Fig. 4. 1. Vas céramique pour poêle, 2. Fragment céramique oriental.

Fig. 5. La surface de Grind no 9.

Fig. 6. Profile de Cas. 1/2004.

Fig. 7. Profile de Cas. 1/2004 et Cas. 2/2004.

Fig. 8. Profile de Cas. 2/2004.

Fig. 9. Ville de Floci. Grind no 3. Objet decouvertes dans le Cas. 2.

Fig. 10. Plan géneral de l'habitations du Grind no 3 "Avicola" - ouest.

Fig. 11. 1. Pointe du flèche, H. 4/2004, 2. Poids pour le filet, 3. Des bagues decouverts dans le sepultures 67 et 74/2004, 4. hameçon.

Fig. 12. Monnaie, $1521-$ H. 2/2003.

Fig. 13. 1. chandelier, 2. Jarre, H 1 b/2005.

\section{Anca Păunescu, Silviu Oța}

Muzeul Național de Istorie a României

Calea Victoriei 12, sector 3, Bucureşti, 030026 ,

ROMÂNIA

\section{Dana Mihai}

Institutul Național al Monumentelor Istorice

Str.Ienăchiță Văcărescu 16, Sector 4,

Bucureşti 040157, România

Tel. 021.336.54.29 / Fax: 021.336.99.04

e-mail: inmi@inmi.ro

\author{
Gheorghe Matei \\ Muzeul Județean Ialomița, Slobozia
}


